\title{
KONSEP MANUSIA DALAM PERSPEKTIF FILSAFAT PENDIDIKAN ISLAM
}

\author{
Oleh: Muaz Tanjung
}

\begin{abstract}
Abstrak
Manusia merupakan satu hakekat yang mempunyai dua dimensi, yaitu dimensi material dan dimensi immaterial. Ungkapan al-Qur'an untuk menunjukkan konsep manusia terdiri atas tiga kategori, yaitu: (1) al-insan, al-ins, dan al-nas, atau unas, (2) al-basyar dan (3) bany Adam. Meskipun ketiga kata tersebut menunjukkan pada makna manusia, namun secara khusus memiliki penekanan pengertian yang berbeda. Allah yang telah menciptakan segala sesuatu dengan sebaik-baiknya, dan memulai menciptakan manusia dari segumpal tanah, dan Dia ciptakan keturunannya dari jenis saripati berupa air yang hina, lalu Dia sempurnakan penciptaannya. Unsur jasad akan hancur dengan kematian, sedangkan unsur jiwa akan tetap dan bangkit kembali pada hari kiamat. Dia tersusun dariperpaduan dua unsur; segenggam tanah bumi, dan ruh Allah, maka siapa yang hanya mengenal aspek tanahnya dan melalaikan aspek tiupan ruh Allah, maka dia tidak akan mengenal lebih jauh hakikat manusia.
\end{abstract}

Kata Kunci: Al-insan, al-ins, al-nas, al-basyar dan bany Adam.

\section{Pendahuluan}

Manusia merupakan makhluk ciptaan Tuhan yang mengagumkan dan penuh misteri. Dia tersusun dari perpaduan dua unsur; segenggam 
tanah bumi, dan ruh Allah, maka siapa yang hanya mengenal aspek tanahnya dan melalaikan aspek tiupan ruh Allah, maka dia tidak akan mengenal lebih jauh hakikat manusia. ${ }^{1} \mathrm{Al}$-Qur'an sendiri juga menyatakan bahwa manusia memang merupakan makhluk paling sempurna yang diciptakan oleh Allah (Q.S. Al-Tin (95): 4). Ada banyak sekali kelebihan yang diberikan oleh Allah swt kepada manusia yang tidak diberikan kepada makhluk-makhlukNya yang lain (Q.S. Al Isra' (17) : 70). Ada beberapa 'perangkat' yang diberikan Allah swt. kepada manusia yang menjadikannya unggul dan terdepan dari para makhluk lainnya seperti; memiliki daya tubuh yang membuat fisiknya kuat; daya hidupyang membuatnya mampu mengem-bangkan danmenyesuaikan diri dengan lingkungan serta mempertahankan diri menghadapi tantangan; daya akal yang membuatnya memiliki ilmu pengetahuan dan teknologi; daya kalbu yang memungkinkannya bermoral, merasakan keindahan, kelezatan iman, dan kehadiran Allah. ${ }^{2}$

Oleh karena itu, manusia perlu menyadari eksistensi dan tujuan penciptaan dirinya, memahami risalah hidupnya selaku pengemban amanah Allah, melalui arahan dan bimbingan yang berkesinambungan agarkehidupannya menjadi lebih berarti. Hal ini disebabkan karena pada dasarnya segala sesuatu diciptakan dengan adanya satu tujuan. Dengan tujuan itulah kemudian sesuatu difungsikan dan dengan adanya fungsi itulah maka keberadaan sesuatu menjadi berarti. Makalah ini mencoba untuk membahas konsep manusia dalam perspektif filsafat pendidikan Islam.

\section{Pengertian al-Nas, al-Basyr dan Bany Adam}

Secara terminologis, ungkapan al-Qur'an untuk menunjukkan konsep manusia terdiri atas tiga kategori, yaitu: (1) al-insan, al-ins, dan al-nas, atau unas, (2) al-basyardan (3) bany Adam. ${ }^{3}$ Meskipun ketiga kata tersebut menunjukkan pada makna manusia, namun secara khusus memiliki penekanan hlm. 430 .

${ }^{1}$ Nurcholish Madjid, 2000. Islam Doktrin dan Peradaban, Jakarta : Paramadina,

${ }^{2}$ M. Quraish Shihab, 1997. Lentera Hati, Bandung : Mizan. hlm. 132.

${ }^{3}$ Muin Salim, 1994. Konsepsi Politik dalam al-Qur'an, Jakarta: LSIK \& Rajawali Press, hlm. 81. Lihat juga M. Quraish Shihab. 2000. Wawasan Al-Quran: Tafsir Maudhu'i atas Pelbagai Persoalan Umat, Bandung: Mizan, hlm. 278. 
pengertian yang berbeda. Perbedaan tersebut dapat dilihat pada uraian berikut:

a. Kata al-Nas dinyatakan dalam al-Qur'an sebanyak 240 kali dan tersebar dalam 53 surat. ${ }^{4}$ Kata al-nas menunjukkan pada eksistensi manusia sebagai makhluk hidup dan sosial, secara keseluruhan, tanpa melihat status keimanan atau kekafirannya. ${ }^{5}$ Kata al-Nas dipakai al-Qur'an untuk menyatakan adanya sekelompok orang atau masyarakat yang mempunyai berbagai kegiatan (aktivitas) untuk mengembangkan kehidupannya. ${ }^{6}$

Dalam menunjuk makna manusia, kata al-nas lebih bersifat umum bila dibandingkan dengan kata al-Insan. Keumumannya tersebut dapat di lihat dari penekanan makna yang dikandungnya. Kata al-Nas menunjuk manusia sebagai makhluk sosial dan kebanyakan digambarkan sebagai kelompok manusia tertentu yang sering melakukan mafsadah dan pengisi neraka, di samping iblis. Hal ini terlihat pada firman Allah QS. al-Baqarah (2): 24. "Maka jika kamu tidak dapat membuat(nya) - dan pasti kamu tidak akan dapat membuat(nya), peliharalah dirimu dari neraka yang bahan bakarnya manusia dan batu, yang disediakan bagi orang-orang kafir." ${ }^{7}$

Manusia merupakan satu hakekat yang mempunyai dua dimensi, yaitu dimensi material (jasad) dan dimensi immaterial (ruh, akal dan sebagainya). Itulah Tuhan yang Maha Mengetahui yang ghaib dan yang nyata, yang Maha Perkasa lagi Maha Penyayang, Dialah yang telah menciptakan segala sesuatu dengan sebaik-baiknya, dan memulai menciptakan manusia dari segumpal tanah, dan Dia ciptakan keturunannya dari jenis saripati berupa air yang hina, lalu Dia sempurnakan penciptaannya, kemudian Dia tiupkan ke dalam tubuhnya ruh (ciptaan) Nya, dan Dia ciptakan bagimu pendengaran, penglihatan dan hati, namun kamu sedikit sekali bersyukur"

${ }^{4}$ Muhammad Fu'ad 'Abdul Baqi, 1988. al-Mu'jam al-Mufahras li Alfazh alQur'an al-Karim, Qahirah: Dar al-Hadits, hlm. 895-899.

${ }^{5}$ Al-Raghib al-Ishfahaniy, tt. al-Mufradat fi Gharib al-Qur'an, Beirut: Dar al-Ma'arif, hlm. 509.

${ }^{6}$ Musa Asy'ari, 1993. Manusia Pembentuk Kebudayaan dalam Al-Qur'an, Cet. I. Yogyakarta: LESFI, hlm. 25.

${ }^{7}$ Departemen Agama RI, 1998. Al-Qur'an dan Terjemahan. Surabaya: AlHidayah, hlm. 12. 
(QS. al-Sajadah, 32: 6-9). Unsur jasad akan hancur dengan kematian, sedangkan unsur jiwa akan tetap dan bangkit kembali pada hari kiamat. "Manusia itu bertanya, siapa pula yang dapat menghidupkan tulang-belulang yang sudah hancur itu? Katakanlah, yang menghidupkannya adalah (Tuhan) yang telah menghidupkannya untuk pertama kali, dan Dia Maha Mengetahui akan setiap ciptaan" (QS. Yasin, 36: 78-79).

b. Penamaan manusia dengan kata al-Basyar dinyatakan dalam Al-Qur'an sebanyak 36 kali dan tersebar dalam 26 surat. $^{8}$ Secara etimologi albasyar berarti kulit kepala, wajah, atau tubuh yang menjadi tempat tumbuhnya rambut. Penamaan ini menunjukkan makna bahwa secara biologis yang mendominasi manusia adalah pada kulitnya, dibanding rambut atau bulunya. ${ }^{9}$ Pada aspek ini terlihat perbedaan umum biologis manusia dengan hewan yang lebih didominasi bulu atau rambut.

Al-Basyar, juga dapat diartikan mulasamah, yaitu persentuhan kulit antara laki-laki dengan perempuan. ${ }^{10}$ Makna etimologi dapat dipahami adalah bahwa manusia merupakan makhluk yang memiliki segala sifat kemanusiaan dan keterbatasan, seperti makan, minum, seks, keamanan, kebahagiaan, dan lain sebagainya. Penunjukan kata al-basyar ditujukan Allah kepada seluruh manusia tanpa terkecuali, termasuk eksistensi Nabi dan Rasul. ${ }^{11}$ Eksistensinya memiliki kesamaan dengan manusia pada umumnya, akan tetapi juga memiliki titik perbedaan khusus bila dibanding dengan manusia lainnya.

Adapun titik perbedaan tersebut dinyatakan al-Qur'an dengan adanya wahyu dan tugas kenabian yang disandang para Nabi dan Rasul. Sedangkan aspek yang lainnya dari mereka adalah kesamaan dengan manusia lainnya. Hanya saja kepada mereka diberikan wahyu, sedangkan kepada manusia umumnya tidak diberikan wahyu. Firman Allah swt.

8 'Abdul Baqi, al-Mu'jam al-Mufahras, hlm. 153-154.

${ }^{9}$ Al- Raqhib al-Ishfahaniy, al-Mufradat, hlm. 46-49.

${ }^{10}$ Ibnu Manzhur, 1992. Lisan al-'Arab, Juz VII, Mesir: Dar al-Mishriyyah, hlm. 306-315.

${ }^{11}$ Di antaranya lihat, QS. H-d (11): 2. QS. Y-suf (12): 96. QS. al-Kahfi (18): 110. QS. al-Furqan (25): 48. QS. Saba' (34): 28. QS. al-Ahqaf (46): 12. 
"Katakanlah: Sesungguhnya Aku ini manusia biasa seperti kamu, yang diwahyukan kepadaku: "Bahwa Sesungguhnya Tuhan kamu itu adalah Tuhan yang Esa". Barangsiapa mengharap perjumpaan dengan Tuhannya, Maka hendaklah ia mengerjakan amal yang saleh dan janganlah ia mempersekutukan seorangpun dalam beribadat kepada Tuhannya". ${ }^{12}$

Menurut M. Quraish Shihab, kata basyar terambil dari akar kata yang pada umumnya berarti menampakkan sesuatu dengan baik dan indah. Dari kata yang sama lahir kata basyarah yang berarti kulit. Manusia dinamakan basyarah karena kulitnya tampak jelas dan berbeda dengan kulit binatang lainnya. Al-Qur'an menggunakan kata ini sebanyak 36 kali dalam bentuk tunggal dan 1 kali dalam bentuk musanna (dual) untuk menunjukkan manusia dari aspek lahiriah serta persamaannya dengan manusia seluruhnya. ${ }^{13}$

Dengan demikian dapat disimpulkan bahwa penelitian manusia dengan menggunakan kata basyar, artinya mahkluk fisik atau biologis yang suka makan dan berjalan ke pasar. Aspek fisik itulah yang menyebut pengertian basyar mencakup anak keturunan Adam secara keseluruhan. ${ }^{14}$ Al-Basyar mengandung pengertian bahwa manusia akan berketurunan yaitu mengalami proses reproduksi seksual dan senantiasa berupaya untuk memenuhi semua kebutuhan biologisnya, memerlukan ruang dan waktu, serta tunduk terhadap hukum alamiahnya, baik yang berupa sunnatullah (sosial kemasyarakatan), maupun takdir Allah (hukum alam). Semuanya itu merupakan konsekuensi logis dari proses pemenuhan kebutuhan tersebut. Untukitu, Allah swt. memberikan kebebasan dan kekuatan kepada manusia sesuai dengan batas kebebasan dan potensi yang dimilikinya untuk mengelola dan memanfaatkan alam semesta, sebagai salah satu tugas kekhalifahannya di muka bumi.

${ }^{12}$ Departemen Agama RI, 1998. Al-Qur'an dan Terjemahan. Surabaya: AlHidayah, hlm. 460.

${ }^{13}$ Shihab, Wawasan Al-Qur'an, hlm. 277.

${ }^{14}$ Aisyah Bintu Syati, 1999. Manusia dalam Perspektif al-Qur-an terj. Ali Zawawi. Jakarta: Pustaka Firdaus, hlm. 1-2. 
c. Adapun kata bany Adam dan zurriyat Adam, yang berarti anak Adam atau keturunan Adam, digunakan untuk menyatakan manusia bila dilihat dari asal keturunannya. ${ }^{15}$ Dalam Al-Qur'an istilah bany adam disebutkan sebanyak 7 kali dalam 7 ayat. $^{16}$

Penggunaan kata bany Adam menunjuk pada arti manusia secara umum. Dalam hal ini setidaknya ada tiga aspek yang dikaji, yaitu: Pertama, anjuran untuk berbudaya sesuai dengan ketentuan Allah, di antaranya adalah dengan berpakaian guna manutup auratnya. Kedua, mengingatkan pada keturunan Adam agar jangan terjerumus pada bujuk rayu setan yang mengajak kepada keingkaran. Ketiga, memanfaatkan semua yang ada di alam semesta dalam rangka ibadah dan mentauhidkanNya. Kesemuanya itu adalah merupakan anjuran sekaligus peringatan Allah dalam rangka memuliakan keturunan Adam dibanding makhluk-Nya yang lain. ${ }^{17}$ Lebih lanjut Jalaluddin mengatakan konsep bany Adam dalam bentuk menyeluruh adalah mengacu kepada penghormatan kepada nilai-nilai kemanusian. ${ }^{18}$

Dengan demikian dapat disimpulkan bahwa manusia dalam konsep bany Adam, adalah sebuah usaha pemersatu (persatuan dan kesatuan) tidak ada perbedaan sesamanya, yang juga mengacu pada nilai penghormatan menjunjung tinggi nilai-nilai kemanusian serta mengedepankan HAM. Karena yang membedakan hanyalah ketaqwaannya kepada Pencipta. Sebagaimana yang diutarakan dalam QS. Al-Hujarat: 13).

Manusia adalah makhluk yang mulia, bahkan lebih mulia dari malaikat. Setelah Allah menciptakan manusia, Allah memerintahkan semua malaikat untuk memberi hormat sebagai tanda memuliakannya. "Maka ketika telah Aku sempurnakan ia dan Aku tiupkan ruh kepadanya, maka beri hormatlah kepadanya dengan bersujud" (QS. al-Hijr, 15: 29). Kemudian, Kemuliaan manusia ditegaskan dengan jelas, "Sesungguhnya kami telah muliakan anak Ādam, dan Kami angkat mereka dari di darat dan di laut, dan Kami

${ }^{15}$ Shihab, Wawasan Al-Qur'an, hlm. 278.

${ }^{16}$ Abdul Mukti Ro'uf. 2008. Manusia Super. Pontianak: STAIN Pontianak Press, hlm. 39.

${ }^{17}$ Samsul Nizar. 2001. Pengantar Dasar-Dasar Pemikiran Pendidikan Islam. Jakarta: Gaya media Pratama, hlm. 52.

${ }^{18}$ Jalaluddin. 2003. Teologi Pendidikan. Jakarta: PT. Raja Grafindo Persada, hlm. 27. 
beri rezeki mereka dari yang baik-baik, dan Kami lebihkan mereka dari kebanyakan mahkluk kami” (QS. al-Isra', 17: 70).

Dengan demikian, makna manusia dalam al-Qur'an dengan istilah al-nas, al-basyar, dan bany Adam mencerminkan karakteristik dan kesempurnaan penciptaan Allah terhadap makhluk manusia, bukan saja sebagai makhluk biologis dan psikologis melainkan juga sebagai makhluk religius, makhluk sosial dan makhluk bermoral serta makhluk kultural yang kesemuanya mencerminkan kelebihan dan keistimewaan manusia daripada makhlukmakhluk Tuhan lainnya.

\section{Tujuan, Fungsi dan Tugas Penciptaan Manusia}

Manusia memiliki keistimewaan dibanding dengan makhluk Tuhan lainnya di muka bumi ini. Keistimewaan itu bisa kita lihat dari sisi penciptaan fisik maupun personalitas karakternya. Karena keistimewaan itu penciptaan manusia memiliki tujuan, fungsi dan tugas yang berbeda dengan makhluk yang lain.

Al-Qur'an memberikan penjelasan mengenai tujuan, fungsi dan tugas manusia di muka bumi. Tujuan penciptaan manusia adalah untuk mengenal Tuhannya. Karenanya ketika di alam ruh, Allah telah mengambil syahadah atau kesaksian terhadap keberadaan dan keesaannya ${ }^{19}$. Hal ini dijelaskan Allah pada surat al-A'raf (7): 172,

"Dan (ingatlah), ketika Tuhanmu mengeluarkan keturunan anak-anak Adam dari sulbi mereka dan Allah mengambil kesaksian terhadap jiwa mereka (seraya berfirman): "Bukankah Aku ini Tuhanmu?" Mereka menjawab: "Betul (Engkau Tuhan kami), kami menjadi saksi". (Kami lakukan yang demikian itu) agar di hari kiamat kamu tidak mengatakan: "Sesungguhnya kami (bani Adam) adalah orang-orang yang lengah terhadap ini (keesaan Tuhan)". ${ }^{20}$

Sedangkan fungsi manusia diciptakan dijelaskan Allah dalam Al-

${ }^{19}$ Al Rasyidin, 2008. Falsafah Pendidikan Islam: Membangun Kerangka Ontologi, Epistemologi, dan Aksiologi Praktik Pendidikan.Bandung: Citapustaka Media Perintis. hlm. 24.

${ }^{20}$ Departemen Agama RI, op. cit., hlm. 250. 
Qur'an sebagai 'abd atau hamba Allah. Hal ini terdapat dalam firman Allah dalam QS. Azzariyat (51) ayat 56:

"Dan tidaklah aku ciptakan jin dan manusia kecuali untuk beribadah kepadaku". ${ }^{21}$

Kata 'abd sendiri dalam al-Qur'an pertama kali ditemukan dalam QS. al-Alaq (96): 10, kemudian dalam bentuk kata kerja ditemukan dalam QS. al-Fatihah (1): 5. Dari kedua penggunaan kata 'abd tersebut, terlihat bahwa konsep yang terkandung meliputi dua aspek, yaitu aspek subjek yang menyembah, atau manusia dan objek yang disembah.

Dari sisi terminologi, terdapat sejumlah perbedaan pendapat di kalangan ulama tentang makna 'ibadah. Ibn Katsir, misalnya, mendefinisikan 'ibadah dengan menunjuk sifatnya sebagai perbuatan yang menghimpun rasa cinta, penyerahan diri yang sempurna dari seorang hamba kepada Tuhan dan rasa khawatir yang mendalam terhadap penolakan Tuhan. Sedangkan Rasyid Ridha mengemukakan bahwa 'ibadah adalah kesadaran jiwa akan keagungan yang tidak diketahui sumbernya. Kekuatan, hakekat dan wujud sumber tersebut tak terjangkau oleh manusia. Mohammad Syalthout menge-mukakan pengertian yang sama dengan Rasyid Ridha. Ia menyatakan bahwa 'ibadah adalah kesadaran akan adanya kekuasaan yang terbatas yang tak terbatas. Dengan demikian, tanpa adanya kesadaran akan adanya kesa-daran semacam itu, 'ibadah tidak akan terwujud.

Dari beberapa pengertian di atas, dapat diambil kesimpulan bahwa kata 'abd mengandung pengertian nahwa ibadah dalam makna penyerahan diri terhadap hukum-hukum Allah Swt yang menciptakannya. Melalui kata 'abd, Allah Swt ingin menunjukkan salah satu kedudukan manusia sebagai hamba Allah yang mengemban tugas-tugas peribadatan.

Sedangkan tugas manusia sebagai khalifah dapat kita temukan firman Allah Swt dalam QS. al-Fathir (35) ayat 39:

"Dialah yang menjadikan kamu khalifah-khalifah di muka bumi." 22 Ayat tersebutmemberikan penegasan terhadap informasi yang terkandung

${ }^{21}$ Ibid., hlm. 862.

${ }^{22}$ Ibid., hlm. 702. 
dalam ayat-ayat sebelumnya. Kalau ayat sebelumnya menjelaskan bahwa Allah mengetahui apa yang tidak terlihat oleh manusia, maka ayat ini menjelaskan Allah menjadikan manusia sebagai khalifah fi al-ard.

Pengertian khalifah, jika dilihat dari akar katanya yang berasal dari kata khalafa, berarti menggantikan tempat seseorang sepeninggalnya. Kerena itu, khalif atau khalifah berati seorang pengganti. Dengan inilah kata khulafa dan khalaif sebagai bentuk jamak dari kata khalifah telah digunakan dalam al-Qur'an. ${ }^{23}$

Dalam kaitannya dengan tugas manusia sebagai khalifah fi al-ard, Ensiklopedi Islam mengemukakan pengertian bahwa kata khalifah berarti wakil, penggantiatau duta Tuhan di muka bumi atau pengganti Nabi Muhammad saw. dalam fungsinya sebagai kepala pemerintahan. Lebih jauh lagi, khalifah fi al- ard digambarkan sebagai kedudukan yang suci, yakni zill al-Allah fi al- ard (bayang-bayang Allah di muka bumi). ${ }^{24}$

Karena itu istilah khalifah berarti wakil, pengganti, duta, atau representasi Tuhan di muka bumi. Tugas sebagai khalifah meniscayakan manusia untuk mempertanggungjawabkan di hadapan Allah segala perbuatannya menyangkut pelaksanaan tugasnya di muka bumi. Karena itu, selama hidupnya manusia harus mengimplementasikan dirinya sebagai makhluk yang bermoral. Ia harus mempertimbangkan segala perilakunya, karena kedudukannya sebagai wakil Tuhan di muka bumi.

Khalifah dapat juga berarti pengganti Nabi Muhammad saw. dalam fungsinya sebagai kepala negara atau sebagai kepala pemerintahan, baik menyangkut urusan agama maupun urusan dunia. Dalam pengertian ini, sejarah mencatat perkembangan istilah khalifah menjadi khalifah Rasul Allah sebagai sebutan Abu Bakar ra., dan khalifah-khalifah Rasul Allah sebagai sebutan untuk 'Umar bin Khattab.

Semua pandangan tentang khalifah di atas mengisyaratkan satu hal sama bahwa kata khalifah bermakna seseorang yang menggantikan yang lainnya. Hanya saja pada tataran ini terdapat perbedaan yang cukup

\footnotetext{
hlm. 35 .

${ }^{23}$ Qomaruddin Khan,1987 Tentang Teori Politik Islam. Bandung: Pustaka.

${ }^{24}$ Lihat, Dasuki Hafidz, ed., 1993. Ensiklopedi Islam, jilid V, Jakarta: Ikhtiar Baru van Hoeve, hlm. 35.
} 
tajam tentang siapa yang digantikan. Dalam hal ini, Shalih Abdullah mengklarifikasikan pandangan-pandangan itu ke dalam tiga kelompok. Pertama, pendapat yang mengatakan bahwa manusia merupakan spesies yang menggantikan spesiesyang pernah lebih dahulu hidup di bumi. Kedua, pendapat yang mengatakan bahwa istilah khalifah dipakai untuk menunjuk kelompok manusia yang menggantikan kelompok manusia lain. Ketiga, pendapat yang menyatakan bahwa khalifah tidak hanya merujuk kepada "seseorang pengganti" atau "pengikut jejak yang lain" namun lebih jauh, kata itu berarti "pengganti Allah". 25

Untuk memperjelas konteks pemaknaan terhadap kata khalifah, berikut ini gambaran yang diungkapkan QS. al-Baqarah (2) ayat 3.

"Ingatlah ketika Tuhanmu berfirman kepada para Malaikat: Sesungguhnya Aku hendak menjadikan seorang khalifah di muka bumi" Mereka berkata: Mengapa engkau hendak menjadikan (khalifah) di bumi itu orang yang akan membuat kerusakan padanya dan menumpahkan darah, padahal kami senantiasa bertasbih dengan memuji engkau dan mensucikan engkau" Tuhan berfirman sesungguhnya aku mengetahui apa yang tidak kamu ketahui. "’6

Jika kita bisa melihat bagaimana hubungan antara manusia dengan Allah swt. sebagaimana digambarkan dalam surat al-Baqarah ayat 30 di atas, hubungan antara yang mencipta dan yang dicipta. Tampak jelas bahwa penunjukan istilah khalifah lebih cenderung pada pengertian sebagai pengganti Allah. Dengan kata lain, kata itu memiliki pengertian bahwa manusia mempunyai beban normatif untuk menuruti apa yang dikehendaki oleh Allah swt.

Dari pernyataan-pernyataan di atas dapatlah ditarik kesimpulan bahwa pengertian khalifah sebagai wakil Tuhan di muka bumi menuju pada pengertian individual yang dimiliki oleh setiap umat manusia. Semua manusia berhak mendapat predikat yang sama, hanya saja kualifikasi ke-khalifah-annya akan ditunjukkan oleh sejauhmana hasil optimalisasi potensi kemanusiaannya masing-masing.

${ }^{25}$ Shalih Abdullah dalam Tedi Priatna, 2004. Reaktualisasi Paradigma Pendidikan Islam; Ikhtiar Mewujudkan Pendidikan Bernialai Ilahiah dan Insaniah di Indonesia(Cet. I; Bandung: Pustaka Bani Quraisy, hlm. 92.

${ }^{26}$ Departemen Agama RI, op. cit., hlm. 13. 
Pada tahap struktural, al-Qur'an menyebut manusia sebagai nafs, diri ego, ke-aku-an yang terbentuk dari unsur jasad, hayat dan ruh. Sedangkan pada tahap fungsional menurut Musa As'arie, al-Qur'an menyebut manusia sebagai 'abd dan sebagai khalifah. Esensi dari makna dari kedudukan manusia sebagai 'abdAllah meniscayakan adanya ketaatan, ketundukan dan kepatuhan manusia sebagai Sang Pencipta. Sedangkan esensi dan kreatifitas dalam upaya membentuk kebudayaan, yang dalam konteks antropologi merupakan satu proses perwujudan eksistensi manusia. ${ }^{27}$

Konsep khalifah dan 'abd, meski keduanya memiliki dimensi perbedaan yang cukup tegas, tidak lantas bisa dipertentangkan, sebab kedua konsep itu berada dalam mainstream pemikiran yang sama. Menarik untuk dikemukakan di sini penjelasan Tobroni dan Samsul Arifin yang menyatakan bahwa fungsi manusia sebagai 'abd dan khalifah dalam konteks yang lebih makro, atau minimal dalam paradigma tauhid, tidak dipandang kesatuan yang terpisah, tapi mengandung adanya hubungan dialektik yang akan mengantarkan manusia kepada puncak eksistensi kemanusiaannya. ${ }^{28}$

Hasan Langgulung menyatakan bahwa tugas manusia, bukan saja sekedar kesanggupan untuk mengembangkan sifat-sifat Tuhan pada dirinya, tapi lebih jauh adalah kesanggupan manusia untuk mengurus sumbersumber yang ada di bumi. ${ }^{29}$

\section{Potensi Manusia}

Dari kajian tentang manusia yang dihadapkan juga terhadap tugas dan tanggung jawabnya sebagai khalfah yang juga secara kausa material dapat ditarik pengertian bahwa manusia itu terdiri atas dua substansi, yaitu (1) Substansi jasad/materi, yang bahan dasarnya adalah dari materi yang merupakan bagian dari alam semesta ciptaan Allah Swt. dan dalam

${ }^{27}$ Musa Asy'ari, 1992. Manusia Pembentuk Kebudayaan dalam Al-Qur'an, (Yogyakarta: Lembaga Studi Filsafat Islam, hlm. 38.

${ }^{28}$ Lihat Tobroni dan Samsul Arifin, 1994. Islam, Pluralisme Budaya dan Politik Refleksi Teologi untuk Aksi dalam Keberagamaan dan Penddidikan Yogyakarta: SI Press, hlm. 154.

${ }^{29}$ Lihat, Hasan Langgulung, 1977. Asas-asas Pendidikan Islam, Bandung: alMa'arif, hlm. 6. 
pertumbuhan dan perkembangannya tunduk dan mengikuti sunnatullah (aturan, ketentuan hukum Allah yang berlaku di alam semesta); (2) Substansi ruhiyahyaitu dianugerahkannya daya-daya al-'aql, al-qalb dan al-nafs kepada manusia sehingga manusia merupakan benda organik yang mempunyai hakekat kemanusiaan serta mempunyai berbagai alat potensial dan fitrah.

Manusia yang terdiri dari dua substansi, telah dilengkapi dengan alat-alat potensial atau disebut fitrah, yang harus diaktualisasikan dan ditumbuhkembangkan dalam kehidupan nyata di dunia melalui proses pendidikan, untuk selanjutnya dipertanggungjawabkan di hadapan-Nya kelak di akhirat.

\section{Implikasinya Terhadap Pendidikan Islam}

Abdullah Fattah Jalal ${ }^{30}$ telah mengkaji ayat-ayat Al-Qur'an yang berkaitan dengan alat-alat potensial yang dianugerahkan oleh Allah kepada manusia untuk meraih ilmu pengetahuan. Masing-masing alat itu saling berkaitan dan melengkapi dalam mencapai ilmu. Alat-alat tersebut adalah sebagai berikut:

a) Al-lams dan al-syum (alat peraba dan alat penciuman/ pembau), sebagaimana firman Allah dalam QS. al-An'am: 7 dan QS. Yusuf: 94.

b) Al-sam'u (alat pendengaran). Penyebutan alat ini dihubungkan dengan penglihatan dan qalbu, yang menunjukkan adanya saling melengkapi antara berbagai alat itu untuk mencapai ilmu pengetahuan QS. alIsra' (17): 36, QS. al-Mu'minun ( 23): 78, QS. al-Sajadah (32): 9, QS. alMulk (67): 23, dan sebagainya.

c) Al-abshar (penglihatan). Banyak ayat al-Qur'an yang menyeru manusia untuk melihat dan merenungkan apa yang dilihatnya, sehingga dapat mencapai hakekat. Sebagaimana firman Allah QS. al-A'raf (7): 185; QS. Yunus (10): 101; QS. al-Sajadah (32): 27 dan sebagainya.

d) Al-'aql (akal atau daya berpikir). Al-Qur'an memberikan perhatian khusus terhadap penggunaan akal dalam berpikir, sebagaimana firman Allah dalam QS. Ali Imran (3): 191. Al-Qur'an menjelaskan bahwa Islam tegak

${ }^{30}$ Abdullah Fattah Jalal. 1977. Min al-Ushul at-Tarbiyah fi al-Islam Mesir: Dar al Kutub, hlm. 103-110. 
di atas pemikiran sebagaimana firman-Nya dalam QS. al-An'am (6): 50. Dalam al-Qur'an dinyatakan bahwa penggunaan akal memungkinkan diri manusia untuk terus mengingat (al-Zikr) dan memikirkan/ merenungkan ciptaan-Nya sebagaimana dalam QS. al-Ra'd (13): 19. Penggunaan akal memungkinkan manusia mengetahui tanda-tanda (kebesaran/keagungan) Allah serta mengambil pelajaran dari padanya. Dalam beberapa ayat, kata al-nuha digunakan sebagai makna al'uqul sebagaimana firman Allah QS. Thaha (20): 53-54 dan sebagainya.

e) Al-Qalb (kalbu), hal ini termasuk alam ma'rifatyang digunakan manusia untuk dapat mencapai ilmu, sebagaimana firman-Nya QS. al-Hajj (22): 46. QS. Muhammad (47): 24 dan sebagainya. Kalbu ini mempunyai kedudukan khusus dalam ma'rifat Ilahiah, dengan kalbu manusia dapat meraih berbagai ilmu dan ma'rifat yang diserap dari sumber Ilahi dan wahyu itu sendiri diturunkan ke dalam kalbu Nabi Muhammad saw. sebagaimana firman-Nya QS. al-Syu'ara (26): 192-194.

Amanah yang Allah berikan kepada manusia sebagai khalifahNya bukanlah tanpa disertai dengan memberikan potensi Ilahiah yang menyertai eksistensi manusia itu sendiri. Allah dengan sifat al-Rahman dan al-Rahim-Nya memberikan potensi-potensi insani atau Sumber Daya Manusia untuk dikembangkan dan ditingkatkan kualitasnya. Esensi Sumber Daya Manusia yang membedakan dengan potensi-potensi yang diberikan kepada makhluk lainnya merupakan anugerah yang sangat tinggi nilainya. ${ }^{31}$

Alat-alat potensial manusia atau fitrah tersebut harus ditumbuhkembangkan secara optimal terpadu melalui proses pendidikan sepanjang hayatnya. Manusia diberi kebebasan/kemerdekaan untuk berikhtiar mengembangkan alat-alat potensial dan potensi-potensi dasar manusia tersebut. Namun demikian, dalam pertumbuhan dan perkembangan tidak bisa dilepaskan dari adanya batas-batas tertentu, yaitu adanya hukumhukum yang pasti dan tetap menguasai alam, hukum yang menguasai bendabenda maupun masyarakat manusia sendiri, yang tidak tunduk dan tidak pula bergantung pada kemauan manusia. Hukum-hukum inilah yang

${ }^{31}$ Lihat, Achmadi, Ideologi Pendidikan Islam Paradigma Humanisme Teosentris (Cet. I; Pustaka Pelajar, 2005), hlm. 64. 
disebut takdir (keharusan universal atau kepastian umum) sebagai batas akhir dari ikhtiar manusia dalam kehidupan.

Di samping itu, pertumbuhan dan perkembangan alat-alat potensi dan fitrah manusia itu juga dipengaruhi oleh faktor-faktor hereditas, lingkungan alam dan geografis, lingkungan sosio-kultural, sejarah dan faktor-faktor temporal. Dalam ilmu pendidikan, faktor-faktor yang menentukan keberhasilan pelaksanaan pendidikan itu ada 5 (lima) macam, yang saling berkaitan, yaitu faktor tujuan, pendidik, peserta didik, alat pendidikan, dan lingkungan. Karena itulah maka minat, bakat dan kemampuan, skill dan sikap manusia yang diwujudkan dalam kegiatan ikhtiarnya dan hasil yang dicapai dari kegiatan ikhtiarnya tersebut bermacam-macam.

Para ahli pendidikan muslim umumnya sependapat bahwa teori dan praktek kependidikan Islam harus didasarkan pada konsep dasar tentang manusia. Pembicaraan diseputar persoalan ini adalah merupakan suatu yang sangat vital dalam pendidikan. Tanpa kejelasan tentang konsep ini pendi-dikan akan meraba-raba. Bahkan menurut Ali Ashraf, pendidikan Islam tidak akan difahami secara jelas tanpa terlebih dahulu memahami penafsiran Islam tentang pengembangan individu seutuhnya. ${ }^{32}$

Pada uraian terdahulu telah dikemukakan tentang filsafat penciptaan manusia dan fungsi penciptaannya dalam alam semesta. Dari uraian tersebut, paling tidak ada 2 (dua) implikasi terpenting dalam hubungannya dengan pendidikan Islam, yaitu:

1. Karena manusia adalah makhluk yang merupakan resultan dari dua komponen (materi dan immateri), maka konsepsi itu menghendaki proses pembinaan yang mengacu kearah realisasi dan pengembangan komponen-komponen tersebut. Hal ini berarti bahwa sistem pendidikan Islam harus dibangun di atas konsep kesatuan (integrasi) antara pendidikan Qalbiyahdan Aqliyahsehingga mampu menghasilkan manusia muslim yang pintar secara intelektual dan terpuji secara moral. Jika kedua komponen itu terpisah atau dipisahkan dalam proses kependidikan Islam, maka manusia akan kehilangan keseimbangan dan tidak akan pernah menjadi pribadi-pribadi yang sempurna (al-insan al-kamil).

${ }^{32}$ Ali Ashraf, 1989. Horison Baru Pendidikan Islam. Jakarta: Pustaka Progresif, 1989, hlm. 1. 
2. Al-Qur'an menjelaskan bahwa fungsi penciptaan manusia di alam ini adalah sebagai 'abd dan tujuannya adalah sebagai khalifah. Untuk melaksanakan fungsi dan tujuan ini Allah SWT membekali manusia dengan seperangkat potensi. Dalam konteks ini, maka pendidikan Islam harus merupakan upaya yang ditujukan kearah pengembangan potensi yang dimiliki manusia secara maksimal sehingga dapat diwujudkan dalam bentuk konkrit, dalam arti berkemampuan menciptakan sesuatu yang bermanfaat bagi diri, masyarakat dan lingkungannya sebagai realisasi fungsi dan tujuan penciptaannya, baik sebagai khalifah maupun 'abd.

Kedua hal di atas harus menjadi acuan dasar dalam menciptakan dan mengembangkan sistem pendidikan Islam masa kini dan masa depan. Fungsionalisasi pendidikan Islam dalam mencapai tujuannya sangat bergantung pada sejauh mana kemampuan umat Islam menterjemahkan dan merealisasikan konsep filsafat penciptaan manusia dan fungsi penciptaannya dalam alam semesta ini. Untuk menjawab hal itu, maka pendidikan Islam dijadikan sebagai sarana yang kondusif bagi proses transformasi ilmu pengetahuan dan budaya Islami dari satu generasi kepada generasi berikutnya. Dalam konteks ini dipahami bahwa posisi manusia sebagai khalifah dan 'abd menghendaki program pendidikan yang menawarkan sepenuhnya penguasaan ilmu pengetahuan secara totalitas, agar manusia tegar sebagai khalifah dan taqwa sebagai subtansi dan aspek 'abd. Sementara itu, keberadaan manusia sebagai resultan dari dua komponen (materi dan immateri) menghendaki pula program pendidikan yang sepenuhnya mengacu pada konsep equilibrium, yaitu integrasi yang utuh antara pendidikan aqliyah dan qalbiyah.

\section{Kesimpulan}

Terminologi manusia yang digambarkan dengan istilah al-basyar, al-insan dan al-nas merupakan kausa prima yang secara fitrah sebagai potensi dasar manusia sekaligus menjadi karakter personalitas dari eksistensi manusia. Konsep kausa material ini sepenuhnya menjadi keistimewaan manusia yang membedakannya dari makhluk lain di muka bumi serta berimplikasi kepada adanya peran dan tugas kekhalifahan.

Manusia sebagai kausa material terdiri atas dua substansi, yaitu 
(1) Substansi jasad / materi, yang bahan dasarnya adalah dari materi yang meru-pakan bagian dari alam semesta ciptaan Allah Swt. dan dalam pertumbuhan dan perkembangannya tunduk dan mengikuti sunnatullah (aturan, ketentuan hukum Allah yang berlaku di alam semesta); (2) Substansi immateri non jasadi yaitu penghembusan / peniupan ruh (ciptaan-Nya) ke dalam diri manusia sehingga manusia merupakan benda organik yang mempunyai hakekat kemanusiaan serta mempunyai berbagai alat potensial dan fithrah.

Pendidikan Islam dalam mencapai tujuannya sangat bergantung pada sejauh mana kemampuan umat Islam menerjemahkan dan merealisasikan konsep filsafat penciptaan manusia dan fungsi penciptaannya dalam alam semesta ini. Untuk menjawab hal itu, maka pendidikan Islam dijadikan sebagai sarana yang kondusif bagi proses transformasi ilmu pengetahuan dan budaya Islami dari satu generasi kepada generasi berikutnya. 


\section{DAFTAR PUSTAKA}

'Abdul Baqi, Muhammad Fu'ad. 1988. al-Mu'jam al-Mufahras li Alfazh al-Qur'an al-Karim, .Qahirah: Dar al-Hadits

Achmadi. 2005. Ideologi Pendidikan Islam Paradigma Humanisme Teosentris.(Cet. I; Pustaka Pelajar

Ali, Ashraf. 1989. Horison Baru Pendidikan Islam. Jakarta: Pustaka Progresif Al-Ishfahaniy, al-Raghib. tt. al-Mufradat fi Gharib al-Qur'an, Beirut: Dar al-Ma'arif

Al Rasyidin. 2008. Falsafah Pendidikan Islam: Membangun Kerangka Ontologi, Epistemologi, dan Aksiologi Praktik Pendidikan. Bandung: Citapustaka Media Perintis

Asy'ari, Musa. 1992. Manusia Pembentuk Kebudayaan dalam Al-Qur'an, Cet. I. Yogyakarta: LESFI.

Departemen Agama RI. 1998. Al-Qur'an dan Terjemahan Surabaya: Al-Hidayah.

Hafidz, Dasuki (ed.). 1993. Ensiklopedi Islam, jilid V, Jakarta: Ikhtiar Baru van Hoeve

Madjid, Nurcholish. 2000. Islam Doktrin dan Peradaban, Jakarta : Paramadin.

Shihab, M. Quraish. 1997. Lentera Hati, Bandung : Mizan

Shihab, M. Quraish. 2000. Wawasan Al-Quran: Tafsir Maudhu'i atas Pelbagai Persoalan Umat, Bandung: Mizan

Salim, Muin.1994. Konsepsi Politik dalam al-Qur'an, Jakarta: LSIK \& Rajawali Press

Jalaluddin. 2003. Teologi Pendidikan. Jakarta: PT. Raja Grafindo Persada. Jalal, Abdullah Fattah. 1977. Min al-Ushul at-Tarbiyah fi al-Islam Mesir: Dar al Kutub.

Khan, Qomaruddin. 1987. Tentang Teori Politik Islam, Bandung: Pustaka 
Langgulung, Hasan. 1977. Asas-asas Pendidikan Islam. Bandung: al-Ma'arif. Manzhur, Ibnu. 1992. Lisan al- 'Arab, Juz VII, Mesir : Dar al-Mishriyyah.

Nizar, Samsul. 2001. Pengantar Dasar-Dasar Pemikiran Pendidikan Islam. Jakarta: Gaya media Pratama.

Priatna, Tedi, 2004. Reaktualisasi Paradigma Pendidikan Islam; Ikhtiar Mewujudkan Pendidikan Bernilai Ilahiah dan Insaniah di Indonesia Cet. I; Bandung: Pustaka Bani Quraisy

Ro'uf, Abdul Mukti. 2008. Manusia Super. Pontianak: STAIN Pontianak Press.

Syati, Aisyah Bintu. 1999. Manusia dalam Perspektif al-Qur-an terj. Ali Zawawi. Jakarta: Pustaka Firdaus.

Tobroni dan Samsul Arifin, 1994. Islam, Pluralisme Budaya dan Politik Refleksi Teologi untuk Aksi dalam Keberagamaan dan Penddidikan. Yogyakarta: SI Press 